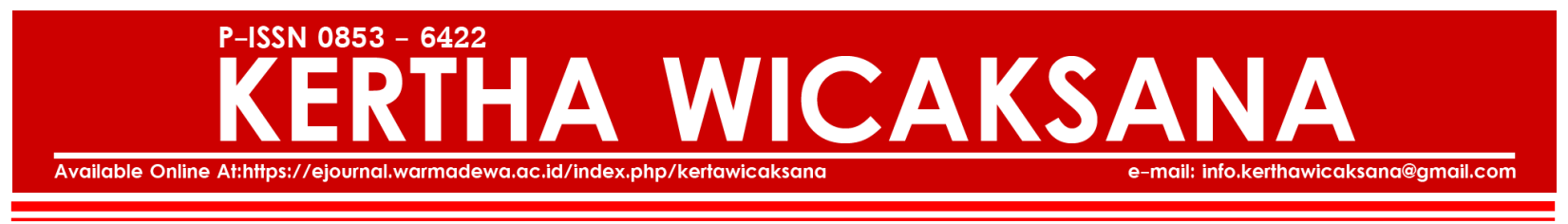

\title{
EKSISTENSI DESA PAKRAMAN DALAM PENGELOLAAN \\ KEPARIWISATAAN BUDAYA BALI \\ (Kajian Terhadap Peraturan Daerah Provinsi Bali No 2 Tahun 2012, tentang Kepariwisataan Budaya Bali)
}

\author{
AA Gede Oka Parwata ${ }^{1}$, I Ketut Kasta Arya Wijaya ${ }^{2}$ \\ Fakultas Hukum Universitas Udayana Denpasar Bali, ${ }^{1}$ \\ Fakultas Hukum Universitas Warmadewa Denpasar Bali ${ }^{2}$ \\ *Email: agungparwata34@yahoo.co.id ${ }^{1}$ \\ *Email: kastaaryawijaya@gmail.com²
}

DOI: $10.22225 / K W .12 .1 .415 .69-75$

Halaman: 69-75

\begin{abstract}
Abstrak
Kegiatan pembangunan kepariwisataan dalam kehidupan Negara modern tidak akan dapat berjalan dengan baik tanpa adanya sebuah kebijakan yang baik pula. Kepariwisataan dalam program suatu negara dihandalkan dan diarahkan untuk memberi manfaat bagi kesejahteraan bersama elemen berbangsa. Nilai dasar atas upaya mewujudkan kemakmuran ditetapkan melalui Undang-Undang No.10 Tahun 2009 tentang Kepariwisataan untuk menciptakan iklim yang kondusif dan memberikan kepastian hukum. Dalam penyelenggaraan kepariwisataan utamanya di Bali menjadi penting pada pengembangan pariwisata budaya sebagai penyangga agar terhindar dari komersialisasi dan komodifikasi yang hanya menempatkan Bali sebagai objek eksploitasi. Desa pakraman berkait dengan kepariwisataan ini memerlukan hak/kepastian berdasarkan hukum sehingga hak dan kewajiban serta kewenangannya guna mendapat jaminan atas kepastian hukum, keadilan dan kemanfaatan seluruh kompenen terkait dalam pengelolaan kepariwisataan. Jenis penelitian ini adalah yuridis normatif yaitu yang mengkaji semua permasalahan melalui tinjauan hukum, acuannya dilakukan baik secara normatif maupun berdasarkan doktrin ilmu hukum. Pembahasan atas kewenangan desa pakraman tidak bisa lepas dari ketentuan Pasal 18B (2) UUD Negara Republik Indonesia Tahun 1945, sebagai pengakuan hak konstitusionalnya. Pengaturan pengelolaan kepariwisataan budaya Bali belum secara implisit mengatur bagaimana hak, kewajiban serta kewenangan yang dimiliki desa pakraman. Sepantasnya dalam Pengelolaan Kepariwisataan budaya memberikan tempat yang rasional kepada desa pakraman sebagai subyek pemilik kebudayaan. Peraturan Daerah Provinsi Bali tentang Kepariwisataan Budaya tidak secara tegas memberikan kedudukan hukum (hak, kewajiban dan wewenang) desa pakraman dalam pengelolaan Kepariwisataan Budaya Bali. Posisi kedudukannya selaku subyek internal, seharusnya diwujudkan dalam bentuk fungsi penguatan, pemberdayaan. Jika dibentuk dalam relasi koordinasi dengan unsur pemerintah daerah pun koordinasi dalam dengan sifat mendukung dan menguatkan kedudukan hukum desa pakraman.
\end{abstract}

Kata Kunci : Kedudukan Hukum, Desa Pakraman, Kepariwisataan Budaya

\begin{abstract}
Tourism development activities in a modern country cannot work well without a good policy. Tourism as one of development programs of a country is a reliable way to bring prosperity to all of the people. The basic value of efforts to achieve prosperity is stated in Act No. 10 Year 2009, which is about tourism for creating a conducive environment and to provide legal certainty. Cultural tourism development activities, particularly in Bali, play an important role as a buffer to avoid Bali from being commercialised and commodified, in other words, being an exploited object. The customary village (desa pakraman) must be given a clear portion in the law regarding tourism industry so that its rights, obligations and authorities to give legal certainty, justice and benefits are clear. This is a normative juridical study, which is a study that analyses all problems through legal perspective whose reference is obtained normatively or based on the doctrines in law discipline. Discussing the authority of Desa Pakraman cannot disregard Article $18 B$ (2) Constituion of 1945, which is a recognition of the rights of customary village. The regulations about cultural tourism of Bali have not yet implicitly defined the rights, obligations and authorities of desa pakraman. Cultural tourism management should provide desa pakraman with a rational
\end{abstract}


portion as the subject and owner of Bali culture. Bali provincial regulation on cultural tourism does not explicitly give the legal status (rights, obligations and responsibilities) of desa pakraman in the management of Bali cultural tourism. As the internal subject, the legal status of desa pakraman should be manifested in the form of both reinforcement and empowerment functions. If the legal status of desa pakraman is in the form of a coordinative relation local government, such coordination should be supporting and strengthening the legal status of desa pakraman.

\section{Keywords: Legal Status, Customary Village (Pakraman), Cultural Touris}

\section{PENDAHULUAN}

Dalam era globalisasi sekarang ini, kegiatan pembangunan kepariwisataan tidak akan dapat berjalan dengan baik tanpa adanya sebuah kebijakan yang baik. Setiap pelaku pariwisata dan terlebih lagi para birokrat, baik di lingkungan pemerintah pusat maupun Pemerintah Daerah, harus memiliki pemahaman yang mendalam tentang pentingnya menyusun dan mengimplementasikan kebijakan yang baik dalam kegiatan kepariwisataan. ${ }^{1}$ Kepariwisataan tidak hanya berkaitan dengan fenomena orang yang melakukan perjalanan, tetapi juga berdampak terhadap masalahmasalah seperti pencapain tujuan sosial dan budaya, kebijakan luar negeri, pembangunan ekonomi, perlindungan lingkungan hidup dan perencanaan pembangunan yang berkelanjutan. ${ }^{2}$

Kepariwisataan Bali telah menjadi sumber penghidupan masyarakat Bali dan menjadi satu tumpuan perekonomian masyarakat. Melihat kondisi itulah pengelolaannya harus diarahkan untuk memberi manfaat bagi kesejahteraan bersama elemen berbangsa. Nilai dasar yang ditetapkan Undang-Undang No.10 Tahun 2009 tentang Kepariwisataan mengamanatkan agar kepariwisataan diarahkan untuk menciptakan iklim yang kondusif sehingga usaha pariwisataisa berkembang dan dapat membuka kesempatan yang sama dalam berusaha dan memfasilitasi, serta dapat memberikan kepastian hukum. Untuk itu diperlukan kebijakan strategis dalam pengelolaannya sehingga tidak ada elemen masyarakat Bali yang tak tersentuh apalagi termarjinalkan. Dalam hal kepariwisataan yang berbasis budaya, Peraturan Daerah No. 2 Tahun2012 tentang Kepariwisataan Budaya telah menempatkan desa pakraman sebagai penyangga kepariwisataan budaya agar terhindar dari komersialisasi dan komodifikasi yang melampaui batas dan hanya menjadikan Bali sebagai objek eksploitasi. Untuk itu perlu kajian lebih mendalam terkait dengan proposionalitas pengelolaan kepariwisataan budaya yang melibatkan peran desa pakraman di dalamnya. hak dan kewajiban serta kewenangan desa pakraman haruslah jelas guna memberi jaminan atas kepastian hukum, keadilan dan kemanfaatan

Desa pakraman yang sejak semula keberadaannya menjaga ketertiban dan kedamaian kehidupan, menjaga keseimbangan dan keharmonisan berbagai kepentingan warga yang ada di dalam dirinya, kini harus menghadapi kenyataan pahit, menahan langkah dengan penuh perhitungan dalam menggunakan hak dan kewenangan dalam mengatur wilayahnya sebagai akibat intrusi berbagai nilai kehidupan masyarakat modern. Keadaan ini dirasakan secara penuh oleh beberapa desa pakraman dalam berbagai bentuknya seperti: cara berfikir, cara bersikap, cara berperilaku warga desa pakraman, perubahan situasi sosial, peningkatan ketegangan dan konflik sosial, dan hambatan serius dalam menggunakan hak-hak sejarah dan kulturalnya seperti dalam mengelola dan mengatur wilayahnya. $^{3}$

Latar belakang pemikiran ini berpijak dari konsepsi kebudayaan sebagai wujud ide, wujud aktivitas, dan wujud benda-benda hasil karya manusia. Kebudayaan tidak semata-mata dipandang sebagai koleksi barangbarang atau benda-benda kebudayaan, melainkan hasil dari cara berfikir manusia dalam merspon dan mengartikulasikan segala sebab yang mengakibatkan manusia memikirkan dan menciptakan sesuatu untuk merespon sebab itu. Dulu orang berpendapat bahwa kebudayaan meliputi segala manifestasi dari kehidupan manusia yang berbudi luhur dan yang bersifat rohani, dewasa ini kebudayaan diartikan sebagai manifestasi kehidupan setiap orang dan setiap kelompok orang.

Kini kebudayaan dipandang sebagai sesuatu yang lebih dinamis, bukan sesuatu yang kaku atau statis. Dulu kata "kebudayaan" dipandang sebagai sebuah kata benda, kini lebih sebagai kata kerja. Kebudayaan bukan lagi pertama tama sebuah koleksi barang-barang kebudayaan, kini kebudayaan terutama dihubungkan dengan kegiatan manusia yang membuat alat-alat,

1. Basuki Antarikasa, 2016. Kebijakan Pembangunan Kepariwisataan, Pengembangan Kepariwisataan yang Berkelanjutan dan perlindungan Kekayaan Intelektual, Intrans Publishing, Malang, h.5

2. Ibid. h. 10

3. IB Wyasa Putra, 2010, "HAM Versus HAM Krama Desa Dalam Penerapan Sanksi Adat " dalam Wicara Lan Pamidadnda, (Ed. Kt Sudantra dan AA Gede Oka Parwata) Udayana University Press, Denpasar, h.114-115.

4. Keontjaraningrat membagi wujud kebudayaan atas tiga wujud, yaitu : wujud Kebudayaan sebagai konplek ide, gagasan, nilai, norma, peraturan, dan sebagainya; wujud kebudayaan sebagai komplek aktivitas dan kelakuan berpola manusia dan wujud kebudayaan sebagai benda-benda hasil karya manusia, lihat Kebudayaan Mentalitas dan Pembangunan, 1981, Gramedia Bandung, h 5

5. Wyasa Putra, dkk. 2013. Naskah Akademik Rancangan Peraturan Daerah Provinsi Bali tentang Pelestarian Warisan Budaya Bali, Dinas Kebudayaan Provinsi Bali, h 5 dan 6 (selanjutnya disingkat Wyasa Putra I) 
dengan tata upacara. Memang dalam pengertian kebudayaan juga termasuk tradisi, dan "tradisi" dapat diterjemahkan dengan pewarisan atau penerusan norma -norma, adat - istiadat, kaidah - kaidah, harta - harta. Tetapi tradisi tersebut bukanlah sesuatu yang tidak dapat diubah, tradisi justru diperpadukan dengan aneka ragam perbuatan manusia. Manusialah yang membuat sesuatu dengan tradisi itu, ia menerimanya, menolaknya atau mengubahnya. Itulah sebabnya kebudayaan merupakan cerita tentang perubahanperubahan riwayat manusia yang selalu memberi wujud baru pada pola-pola kebudayaan yang sudah ada $^{6}$ di samping itu pula kebudayaan merupakan hasil dari cara-cara manusia menerobos fakta-fakta alam dengan cara mengevaluasi, dan kemudian menuangkan dalam suatu bentuk kebijakan dan keputusan. Faktafakta alam merupakan lingkaran yang mengurung manusia dalam keniscayaan alam di satu pihak dan keterbukaan yang dicapai berdasarkan penilaian yang kritis oleh pihak lainnya ${ }^{7}$

Berdasar fakta hukum demikian, maka permasalahan yang akan dikaji melalui penelitian ini adalah :

A. Bagaimana hak dan kewajiban desa pakraman dalam pengelolaan kepariwisataan budaya Bali ?

B. Bagaimanakan kewenangan desa pakraman dalam melakukan pengelolaan kepariwisataan budaya Bali ?

\section{HASIL DAN PEMBAHASAN}

Secara formal, istilah desa pakraman pertama kali digunakan dalam Peraturan Daerah No.3 Tahun 2001 tentang Desa Pakraman. Dalam Pasal 1 angka 4 disebutkan:

"Desa Pakraman adalah kesatuan masyarakat hukum adat di Provinsi Bali yang mempunyai satu kesatuan tradisi dan tata krama pergaulan hidup masyarakat umat Hindu secara turuntumurun dalam ikatan Kahyangan Tiga atau Kahyangan Desa yang mempunyai wilayah tertentu dan harta kekayaan sendiri serta berhak mengurus rumah tangganya sendiri”.

Dari konsepsi tersebut di atas dapat dikemukakan bahwa desa pakraman bersifat otonom dalam arti mempunyai hak dan kewajiban untuk mengatur dan mengurus rumah tangganya sendiri sesuai dengan kebijaksanaan, prakarsa, dan kemampuannya sendiri ${ }^{8}$ atau merupakan kekuatan untuk mengatur warganya sehingga segala kepentingannya dapat dipertahankan ${ }^{9}$
Desa pakraman sebagai kesatuan masyarakat hukum adat yang masih hidup, keberadaan dan hakhak tradisional yang dimiliknya dilindungi oleh Konstitusi (UUD.NRI 1945). Pasal 18B ayat (2). Ini berarti konstitusi mengakui bahwa desa pakraman mempunyai kemampuan hukum (legal capacity) untuk mempertahankan hak-hak tradisionalnya di hadapan pengadilan. Kemampuan hukum tersebut bukan hanya terhadap perbuatan orang perorangan tetapi juga terhadap perbuatan negara.

Karena hak-hak tradisional itu secara tegas diakui oleh Konstitusi, maka hak-hak itu berstatus sebagai hak konstitusional sehingga pelanggaran terhadap terhadap hak-hak itu merupakan pelanggaran konstitusional. Undang-undangpun tidak boleh melanggar hak-hak tradisional desa pakraman yang telah diakui sebagai hak konstitusional. Itulah sebabnya, Undang-Undang Nomer 24 tahun 2003 tentang Mahkamah Konstitusi (selanjutnya disebut UUMK memberi kedudukan hukum (legal standing, pesona standi in yudicio) kepada kesatuan masyarakat sepanjang memenuhi persyaratan, untuk bertindak sebagai pemohon dalam pengujian undang-undang terhadap UUD 1945,

Desa pakraman yang merupakan lembaga sosial tradisional mewadahi kegiatan sosial, budaya, dan keagamaan masyarakat umat Hindu di Bali dilandasi oleh falsafah Tri Hita Karana. Dengan adanya falsafah Tri Hita Karana, akan terwujudlah suasana kehidupan yang aman, tenteram, tertib, dan rukun berasaskan kekeluargaan atau kebersamaan atau asas kemasyarakatan. Kondisi kehidupan yang demikian memberikan motivasi tumbuhnya kebudayaan yang berkembang secara kreatif.

Terkait dengan hal tersebut Peraturan Daerah Provinsi Bali Nomer 2 tahun 2012, tentang Kepariwisataan Budaya Bali, BAB I, .Pasal 1 angka 14 menentukan:

"Kepariwisataan budaya Bali adalah kepariwisataan Bali yang berlandaskan kepada kebudayaan Bali yang dijiwai oleh ajaran Agama Hindu dan falsafat Tri Hita Karana sebagai potensi utama dengan menggunakan kepariwisataan sebagai wahana aktualisasinya, sehungga terwujud hubungan timbal balik yang dinamis antara kepariwisataan dan kebudayaan yang membuat keduanya berkembang secara sinergis, harmonis dan berkelanjutan untuk dapat memberikan kesejahteraan kepada masyarakat, kelestarian budaya dan lingkungan"

6. C.A. van Peursen. 1995. Srtategi Kebudayaan, Kanisius, Yogyakarta,h. 11-12

7. Wyasa Putra I, dkk. op. cit. h. 7

8. I Gusti Ngurah Gorda, 1999, Manajemen dan Kepemimpinan Desa A dat di Propinsi Bali,dalamPerspektif Era Globalisasi, STIE, Singaraja dan PT. Widya Kriya Gematama, Denpasar, h. 42

9. I Ketut Wirta Griadhi, 1991, "Peranan Otonomi Desa Adat Dalam Pembangunan" Kerta Patrika, Majalah Ilmiah Fakultas Hukum Unud, No. 54 Tahun XVII, Denpasar, h. 51

10. Palguna, 2010. "Tata Hubungan Desa Pakraman Dengan Desa Dinas" Makalah, disampaikan pada Seminar Desa Pakraman Benteng Pelestarian Budaya Bali, dalam rangka Dies natalis Ke-48 Universitas Udayana, tgl 18 September 2010, h. 4 
BAB II, Pasal 2, mengatur:

"Penyelenggaraan Kepariwisataan budaya Bali dilaksanakan berdasarkan pada asas manfaat, kekeluargaan, kemandirian, keseimbangan, kelestarian, partisipatif, berkelanjutan, adil dan merata, demokratis, kesetaraan dan kesatuan yang dijiwai oleh nilai-nilai Agama Hindu dengan menerapkan falsafah Tri Hita Karana".

Selanjutnya dalam Pasal 3 diatur:Kepariwisataan Budaya Bali bertujuan:

1. Melestarikan kebudayaan Bali yang dijiwai oleh nilai-nilai Agama Hindu;

2. Meningkatkan pertumbuhan ekonomi

3. Meningkatkan kesejahteraan masyarakat

4.

5.

6. Melestarikan alam, lingkungan dan sumber daya;

7.

8.

Dalam BAB III, Pasal 4, mengatur : Pembangunan Kepariwisataan Budaya Bali diarahkan:

1. Meningkatkan harkat dan martabat, serta memperkukuh jati diri masyarakat Bali;

2. Meningkatkan kesejahteraan masyarakat Bali secara merata dan berkelanjutan; dan

3. Melestarikan lingkungan alam Bali sebagai basis penyangga kehidupan masyarakat dan kebudayaan Bali secara berkelanjutan,

Dalam Pasal 24 ditentukan:

1. Masyarakat berhak memperoleh kesempatan yang seluas-luasnya untuk berperan serta dalam menyelenggarakan kepariwisataan;

2. hak sebagaimana dimaksud pada ayat (1) mencakup:

a. Sebagai pekerja pada usaha pariwisata;

b. Sebagai pengelola Daya Tarik Wisata;

c. Melaksanakn promosi, dan

d. Duduk dalam kelembagaan pariwisata.

Pasal 25 diatur: Desa pakraman dan/atau lembaga tradisional lainnya, dapat bekerjasama dengan pemerintah daerah melakukan usaha-usaha untuk mencegah aktivitas kepariwisataan yang tidak sesuai dengan kepariwisataan budaya Bali

Tidak bisa dipungkiri desa pakraman merupakan suatu sistem sosial yang mapan dan fungsional dalam mendukung keberadaan kebudayaan Bali yang bersumber dari agama Hindu serta merupakan basis penerapan dan pengembangan nilai-nilai agama Hindu dan budaya Bali. Dengan demikian secara tidak langsung sangat fungsional bagi pengembangan pariwisata di Bali.

Sebagai pendukung atau rumah kebudayaan sudah sepantasnya secara tegas diatur hak dan kewajibannya desa pakraman dalam mengelola kepariwisataan budaya. Apalagi UUD 1945, Pasal 18B (2) mengakui hak-hak yang dimilikinya dilindungi oleh konstitusi. Kalau diperhatikan ketentuan pasal-pasal dari Perda Kepariwisataan Budaya sebagaimana dikemukakan di atas tidak ada satupun pasal yang secara tegas menyebut secara implisit apa hak dan kewajiban desa pakraman dalam pengelolaan kepariwisataan budaya. Memang dalam BAB IX, Pasal 24, (1), (2), Pasal 25, diatur tentang Peran Serta Masyarakat, sedangkan dalam BAB X, Pasal 26 (2) diatur Hak, Kewajiban, dan Larangan,: "Desa pakraman dan lembaga tradisional mempunyai hak untuk mengembangkan wisata pedesaan sesuai dengan potensi setempat". Ketentuan pasal ini hanya mengatur hak untuk mengembangkan wisata pedesaan, tetapi tidak diatur lebih lanjut kewajiban-kewajiban apa yang harus dilakukan dan bagaimana pengaturan dan implementasi dari hak-hak tersebut. Hal ini perlu ditekankan karena desa pakraman dalam pengaturan objek wisatanya disamping berpedoman aturan tertulis (Perda, Undang-undang) juga dibuatkan aturan dalam awig-awig atau peraremnya dalam pengelolaannya.

Mengacu pada konsep pluralisme atau kemajemukan hukum dari Griffths yang dikutip dari Sulastriyono $(2000)^{11}$ membagi pluralisme hukum atau kemajemukan hukum menjadi dua yaitu weak legal pluralism (pluralisme hukum yang lemah) mengandung makna bahwa suatu kemajemukan hukum yang berusaha melakukan penggabungan atau perujukan antara hukum adat dengan hukum negara. Strong legal pluralism (pulralisme hukum yang kuat) yaitu adanya berbagai hukum yang berlaku dalam berbagai lapangan sosial tertentu tanpa harus merujuk pada hukum negara. Berdasarkan hal tersebut dalam kaitan dengan pengelolaan obyek wisata oleh desa pakraman terdapat beberapa aturan atau hukum yang berlaku, seperti Perda (hukum tertulis) dan hukum lokal (tidak terulis/hukum adat atau atau awig-awig atau perarem). Dalam pengaturan Kepariwisataan budaya, dipandang perlu untuk mendapat penekanan yaitu bagaimanakan kedua sistem hukum tersebut bekerja dalam kenyataannya dan bagaimana implikasinya saling pengaruh kedua sistem hukum tersebut? Dengan demikian dapat dihindari terjadinya konflik pengaturan sehungga perlu diperjelas kedudukan desa pakraman dalam pengaturan kepariwisataan budaya Bali.

Membahas kewenangan desa pakraman tidak bisa lepas dari ketentuan Pasal 18B (2) UUD. NRI Tahun 1945, sebagai pengakuan hak konstitusionalnya, Peraturan Daerah Provinsi Bali Nomer 3 tahun 2001

11. Sulatriyono, 2000, "Pluralisme Hukum dan Permasalahan Pertanahan, Kasus Penguasaan Tanah Timbul di Muara Sungai Citandui", dalam Hukum dan Kemajemukan Budaya (EKM.Masinambow- Ed), h.183-184. 
tentang Desa Pakraman, serta otonomi desa pakraman. Perda Desa Pakraman Nomer 3 tahun 2001 dalam Ketentuan Umum, Pasal 1 angka 4, menyatakan:

"Desa pakraman adalah kesatuan masyarakat hukum adat di Propinsi Bali yang mempunyai satu kesatuan tradisi dan tata karma pergaulan hidup masyarakat umat Hindu secara turun temurun dalam ikatan Kahyangan Tiga atau Kahyangan Desa yang mempunyai wilayah tertentu serta berhak mengurus rumah tangganya sendiri'"

Kewenangan desa pakraman "diatur" dalam Pasal 6 Peraturan Daerah Provinsi Bali Nomer 3 Tahun 2001. Desa pakraman mempunyai wewenang sebagai berikut:

1. Menyelesaikan sengketa adat dan agama dalam lingkungan wilayahnya dengan tetap membina kerukunan dan toleransi antar krama desa sesuai dengan awig-awig dan adat kebiasaan setempat

2. Turut serta menentukan setiap keputusan dalam pelaksanaan pembangunan yang ada di wilayahnya terutama yang berkaitan dengan Tri Hita Karana

3. Melakukan perbuatan hukum di dalam dan luar desa pakraman.

Kata "diatur" menurut Palguna (2010) ${ }^{12}$ perlu diberi tanda petik. Sebab Perda Desa Pakraman bukanlah "sumber hukum" dari kewenangan yang dimiliki desa pakraman melainkan hanya ketentuan yang menunjukkan sekaligus menegaskan atau mengukuhkan bahwa desa pakraman memiliki kewenangan itu. Perda Desa Pakraman bukanlah memberi kewenangan kepada desa pakraman melainkan hanya menegaskan atau menunjukkan bahwa desa pakraman memiliki kewenangan tertentu menurut hukum adat.

Kalau diperhatikan ketentuan pasal 6 (b) Perda Desa Pakraman tersebut di atas seharusnya mempertegas atau mengukuhkan kewenangan desa pakraman termasuk juga dalam pelaksanaan pembangunan yang ada wilayahnya termasuk pembangunan dengan berbasis budaya Bali dalam bingkai Tri Hita Karana.

Dalam menetapkan kebijakan pengaturan kepariwisataan budaya, budaya harus dipandang sebagai sebagai suatu proses manusia beradaptasi dengan lingkungan alam disekitarnya dimana dia tinggal dengan menggunakan akal, pikiran atau budi dayanya. Pengaturan masalah kebudayaan Bali harus memperhatikan komponen terkait satu dengan lainnya dan saling mendukung, seperti, manusia sebagai pendukung kebudayaan, dan alam sebagai wadah kebudayaan itu. Hal ini harus dilakukan secara sistematik, terstruktur dan komprehensif, menyentuh

12. Palguna, IDG. 2010, Op. cit. h. 6

13. Wysa Putra I,dkk, op. cit, h 7 - 8 ketiga komponen tersebut (kebudayaan, manusia dan alam (desa pakraman)

Dalam hubungannya dengan kebijakan pengaturan kepariwisataan budaya hendaknya mencakup:

1. Kebijakan pelestarian budaya, yang disebut kebijakan pokok;

2. Kebijakan penguatan terhadap masyarakat sebagai pemilik dan pendukung kebudayaan itu; dan

3. Kebijakan pemeliharaan lingkungan tempat dimana warisan budaya itu diciptakan, dipelihara dan dikembangkan. Kebijakan b dan c, merupakan kebijakan pendukung. ${ }^{13}$

Potensi budaya yang sangat besar ini sudah semestinya mendapatkan perlindungan di daerah. Namun perlindungan dan pemanfaatan budaya belum terstruktur dan koordinatif dengan proses dan mekanisme yang memperhatikan masyarakat sebagai pemilik kebudayaan itu sendiri.

Dalam hubungan dengan pengelolaan Kepariwisataan Budaya Bali dalam pasal-pasalnya belum secara implisit mengatur bagaimana hak, kewajiban serta kewenangan yang dimiliki desa pakraman dalam pengelolaannya. Dalam peran sebagai penyangga kepariwisataan budaya harus diperjelas kedudukan desa pakraman sebagai satu kesatuan masyarakat hukum adat yang dengan otonominya. Desa pakraman yang keberadaannya menjaga ketertiban dan keamanan dengan menjaga keseimbangan dan keharmonisan sebagai benteng kebudayaan Bali harus dipertegas posisinya dalam pengelolaan kepariwisataan budaya Bali sebagai bentuk pemberdayaan sekaligus peran sertanya menunjang Kepariwisataan Budaya Bali, baik dalam pengelolaan, usaha pariwisata, pembangunan daya tarik pariwisata, pembinaan dan pengawasan.

Sepantasnya dalam Pengelolaan Kepariwisataan budaya memberikan tempat yang rasional kepada desa pakraman sebagai subjek pemilik kebudayaan. Dalam kebijakan pengelola pariwisata budaya di wilayahnya termasuk pemeliharaan yang ada di bawah desa kepemilikan desa pakraman. Paradigma pengelolaan kepariwisataan budaya merupakan skema yang menempatkan desa pakraman sebagai pemilik atau wadah kebudayaan sebagai pelaku pengelolaan karena ada ikatan integral antara kebudayaan dengan masyarakat adat (desa pakraman) sebagai subjek pendukung utama.

Dengan demikian unsur luar dari desa pakraman sebagai unsur eksternal pengelolaan kepariwisataan budaya jika masuk dalam sistem pengelolaan seharusnya mengambil posisi sebagai pendukung bukan sebagai posisi pengelola, atau jika sebagai posisi pengelola harus ada penyerahan posisi kedudukan antara subjek internal (desa pakraman) 
kepada subjek ekternal, yang penyerahannya berdasarkan sifat sukarela dengan pertimbangan dan kehendak subyek internal (desa pakraman). Posisi subyek internal seharusnya diwujudkan dalam bentuk fungsi penguatan, pemberdayaan. Dengan demikian koordinasi dengan kerangka berfikir ini berarti koordinasi dalam sifat mendukung dan menguatkan.

Masalah pengelolaan warisan budaya (termasuk kebudayaan Bali-peneliti) merupakan suatu sistem otonom, yang terdiri dari 3 komponen: ${ }^{14}$

1. Kebudayaan Bali;

2. Masyarakat adat Bali sebagai pemilik warisan budaya Bali;
3. Ruang alam Bali sebagai wadah tempat lahir tumbuh dan berkembangnya kebudayaan Bali.

Kertiga hal tersebut merupakan tiga komponen integral dalam pengelolaan budaya Bali, dan merupakan sistem internal dalam pengelolaan kebuadayaan Bali serta merupakan karakter alamiah budaya Bali. Kebudayaan Bali tidak bisa dilepaskan dari masyarakat sebagai pendukung, serta ruang sebagai tempat atau wadah lahir, hidup, tumbuh dan berkembangnya kebudayaan Bali.Kebudayaan Bali adalah milik masyarakat, desa pakraman dan ruang alam Bali. Kebudayaan Bali memberikan kehidupan, memberi penanda identitas bagi masyarakat adat Bali, karena itu mereka pelihara dan kembangkan.

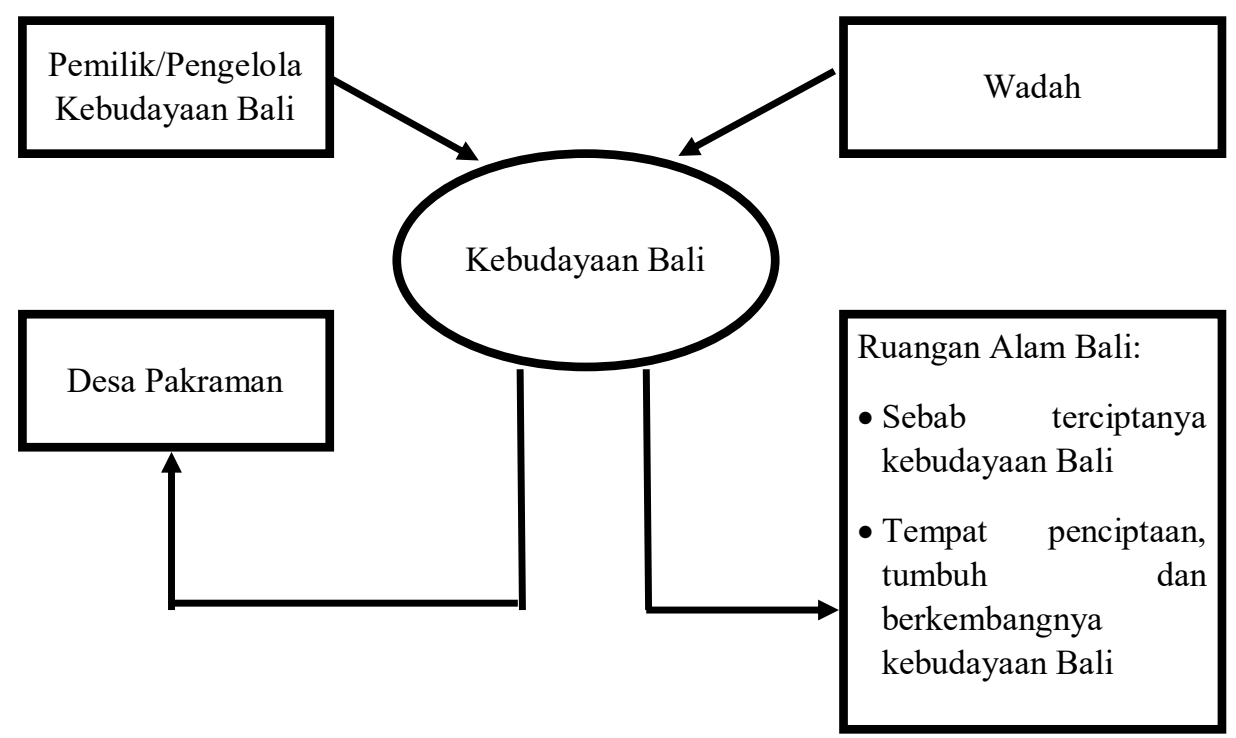

Gambar 1

Komponen dalam pengelolaan kebudayaan Bali

Sumber: Gambar diolah dari Wyasa Putra I (h. 103)

Garis korelasi pada gambar di atas menggambarkan fungsi-fungsi :

1. Fungsi kepemilikan dan pengelolaan;

2. Fungsi tempat atau perwadahan/atmosfir alam terhadap kebudayaan;

\section{Fungsi penanda identitas}

Dengan hadirnya Peraturan Daerah Provinsi Bali Nomer 2 Tahun 2012 tentang Kepariwisataan Budaya Bali, memberi posisi pemerintah maupun swasta dalam pembangunan Kepariwisataan Budaya Bali, baik dalam usaha pariwisata, destinasi pariwisata, pemasaran, maupun kelembagaan kepariwisataan. Dengan demikian akan melahirkan kontruksi baru dalam sistem pengelolaan kebudayaan Bali. Pemerintah dan swasta sebagai pihak eksternal menjadi komponen aktif yang terlibat dalam pengelolaan kepariwisataan budaya Bali. Pemerintah tidak hadir sebagai pemelihara budaya Bali melainkan sebagai pengatur dan bahkan bisa dibilang sebagai penikmat hasil pengelolaan kepariwasataan budaya Bali. Posisi ini bisa melahirkan suatu masalah dalam sistem pengelolaan kepariwisataan budaya Bali, bahkan akan terjadi kesenjangan bahkan diskoneksitas antara komunitas pemilik dan pemelihara budaya Bali dengan pihak ekternal sebagai pengatur. Disatu pihak beban kepemilikan dan pemeliharaan budaya Bali dipikul oleh masyarakat adat, (desa pakraman) manfaat dari hasil pemilikan dan pemeliharaan dinikmati oleh pihak eketernal.

Masalah diskorelasi dan ketimpangan beban dan manfaat komunitas pemilik dan pengelola kepariwisataan budaya Bali dengan pemerintah dan pihak swasta, diperlukan solusi pemecahan masalah:

1. Perlu ada pengembangan saluran komunikasi antara pemerintah, swasta dan masyarakat 
pemilik dan pengelola kepariwisataan budaya Bali;

2. Pendistribusian beban dan manfaat yang seimbang antara masyarakat pengelola kepariwisataan budaya dengan pemerintah. Pemerintah dapat menanggung beban biaya pemeliharaan kepariwisataan budaya dalam bentuk pengalokasian anggaran dalam jumlah tertentu, sedangkan swasta dapat mengalokasikan anggaran melalui program tanggung jawab social perusahaan (Corporate Social ResponsibilityCSR).

3. Menempatkan pengelolaan kepariwisataan budaya Bali kepada desa pakraman dengan sistem pengeloaan, pemeliharaan yang berada di bawah otoritas otonomi desa pakraman.

Terhadap pemecahan yang nomor tiga, dimaksudkan Pemerintah daerah, sebagai representasi negara, (sebagai pihak eksternal) boleh mengatur, tetapi pengaturan itu harus bersifat penghormatan, pengakuan, fasilitasi dan penguatan. Pemerintah daerah harus sebisa mungkin mencegah intervensi terhadap pengelolaan kepariwisataan budaya Bali.

Dengan adanya solusi pemecahan masalah tersebut di atas diharapkan pengelolaan kepariwisataan budaya Bali dapat meningkatkan kondisi dan kualitas objek yang dipelihara dan dikelola itu, yang tetap memberikan porsi kepada desa pakraman baik menyangkut kewenangan, hak maupun kewajibannya dalam bentuk penguatan peran masyarakat adat (desa pakraman).

\section{SIMPULAN}

Desa pakraman merupakan pusat pembinaan kebudayaan Bali, sebab kehidupan agama Hindu, tata kemasyarakatan, kehidupan sosial budaya semuanya bertumpu pada desa pakraman. Inilah yang merupakan modal dasar pembangunan Bali yang tidak ternilai harganya serta menginpirasi lahirnya Peraturan Daerah Provinsi Bali Nomor 2 tahun 2012, namun tidak secara tegas atau langsung memberikan keterkaitan antara pemerintah daerah dengan desa pakraman dalam pengaturan hak, kewajiban dan kewenangan dalam pengelolaan kepariwisataan budaya. Hadirnya Peraturan Daerah tentang Kepariwisataan Budaya Bali, memberi posisi pemerintah maupun swasta dalam pembangunan Kepariwisataan Budaya Bali, baik dalam usaha pariwisata, destinasi pariwisata, pemasaran, maupun kelembagaan kepariwisataan. Dengan demikian tidak menempatkan pengelolaan kepariwisaan budaya Bali kepada desa pakraman dengan sistem pengelolaan, pemeliharaan yang berada di bawah otoritas otonomi desa pakraman dalam kondisi yang tetap memberikan porsi kepada desa pakraman.
Buku :

Basuki Antarikasa, 2016. Kebijakan Pembangunan Kepariwisataan, Pengembangan Kepariwisataan yang Berkelanjutan dan perlindungan Kekayaan Intelektual, Intrans Publishing, Malang,

IB Wyasa Putra, 2010, "HAM Versus HAM Krama Desa Dalam Penerapan Sanksi Adat

"dalam Wicara Lan Pamidadnda,(Ed. Kt Sudantra dan AA Gede Oka Parwata) Udayana University Press, Denpasar.

Mukti Fajar ND dan Yulianto Achmad, 2013, Dualisme Penelitian Hukum Normatif \& Empiris, Pustaka Pelajar, Yogyakarta.

Parwata, A.A. Gede Oka. 2010 "Memahami AwigAwig Desa Pakraman" Wicara lan Pamidanda, Pemberdayaan desa Pakraman Dalam Penyelesaian Perkara di Luar

Pengadilan. (dalam I Ketut Sudantra dan A.A. Gede Oka Parwata- Ed), Edisi

RevisiUdayana University Press, Denpasar.

SAlim HS dan Erlies Septiana Nurbani, 2014, Penerapan Teori Hukum Pada Penelitian Tesis Dan Disertasi,RajaGrafindo Persada, Jakarta.

Sulatriyono, 2000, "Pluralisme Hukum dan Permasalahan Pertanahan, Kasus Penguasaan Tanah Timbul di Muara Sungai Citandui, dalam Hukum dan Kemajemukan Budaya (EKM. Masinambow- Ed), Yayasan Obor Indonesia, jakarta

Wayan P. Windia Dan Ketut Sudantra, 2006, Pengantar Hukum Adat Bali, Lembaga Dokumentasi dan Publikasi Fakultas Hukum Universitas Udayana.

Majalah dan Hasil Seminar :

Palguna, IDG. 2010, “Tata Hubungan Desa Pakraman Dengan Desa Dinas”, Makalah,

dipresentasikan pada Seminar Desa Pakraman Benteng Plestari Budaya Bali, yang diselenggrakan dalam rangka Dies Natalis, bertempat di Denpasar, 18 September 2010.

Wirta Griadhi, 1991, "Peranan otonomi Desa Adat dalam Pembangunan"Kertha Patrika”, Majalah Ilmiah Fakultas Hukum Unud, No 54 Tahun XVII, Denpasar.

Peraturan Perundang-Undangan

Undang- Undang Dasar Negara Republik Indonesia Tahun 1945 .

Undang-Undang Nomor 10 Tahun 2009 tentang Kepariwisataan.

Peraturan Daerah Nomor 2 Tahun 20012 tentang Kepariwisataan Budaya Bali.

Peraturan Daerah Nomor 3 Tahun 2001 tentang Desa Pakraman.

\section{DAFTAR PUSTAKA}

